\title{
Kde začínáme a kde končíme
}

\author{
Jaroslav Petr \\ Výzkumný ústav živočišné výroby v.v.i., Praha-Uhříněves, Česká republika
}

\section{WHERE WE BEGIN AND WHERE WE END}

\begin{abstract}
The horizontal gene transfer and genetic engineering resulted in many crossings of the boundary dividing the human genome from the genomes of other organisms. The horizontal gene transfer is a natural process and cannot be stopped. The genetic engineering is a highly beneficial human activity and we cannot abandon it. Moreover, our ancestors "spilled" our genome with sequences of DNA from several extinct human species. It is necessary to accept that the border of the human genome is not sharply delineated. In the future, the contours of our genome could become even much fuzzier.
\end{abstract}

KEY WORDS human genome; horizontal gene transfer; genetic engineering; Neanderthals; Denisovans

ABSTRAKT Horizontální přenos genů a genové inženýrství vyústily v celou řadu př́padů, kdy došlo k překročení hranic oddělujících lidský genom od genomů jiných organismů. Horizontální přenos genů je ryze přírodní proces, který nedokážeme potlačit. Genové inženýrství je vysoce prospěšná lidská aktivita, jižž se nemůžeme vzdát. Navíc se ukazuje, že naši předci „pošpinili“ náš genom sekvencemi několika vymřelých druhů člověka. Je proto nezbytné přijmout jako fakt, že hranice lidského genomu nejsou jasně vytyčené a že v budoucnu budou jeho obrysy ještě nejasnější.

KLÍČOVÁ SLOVA lidský genom; horizontální přenos genů; genové inženýrství; neandertálci; děnisované

\section{PŘESAHY S PROKARYOTNÍM ŽIVOTEM}

Z geografického hlediska začíná vliv člověka na dně moří a oceánů, třeba v místě vrtu Deepwater Horizon na dně Mexického zálivu. Momentálně snad končí ve vzdálenosti 103 astronomických jednotek od Země, kde se právě americká sonda Pioneer 10 řítí směrem k Aldebaranu v souhvězdí Býka s poselstvím o existenci člověka vyrytým do pozlacené plakety. Z hlediska časového stojí Homo sapiens jednou nohou v dobách svého evolučního zrodu vzdálených ode dneška asi dvě stě tisíc let a tou druhou je nakročen do budoucnosti, $\mathrm{k}$ níž upírá naděje a zároveň se před ní strachuje. Z hlediska biologického a genetického se zdá člověk omezen podstatně více. Jeho existence je spjata s poměrně malým prostorem zhruba tři miliard písmen genetického kódu obsahujícím asi 23000 genů. Fenomén horizontálního přenosu genů i genového inženýrství však genetické kontury člověka poněkud rozmazává. Nedávno se podařilo odhalit $\mathrm{v}$ dědičné informaci bakterie Neisseria gonorrhoeae sekvenci o 685 písmenech genetické- ho kódu, jež mimo jakoukoli pochybnost pochází z lidského genomu (Anderson - Seifert 2011). Je to jen kapka $\mathrm{v}$ moři více než dvou milionů písmen genetického kódu tvořících genom původce kapavky. Navíc je lidská sekvence přítomná jen $\mathrm{v}$ jedné $\mathrm{z}$ devíti populací této bakterie. Přesto jde o jasný genetický přesah člověka do prokaryotní ŕíše.

Nejsme však jen dárci genů, ale také jejich př́ijemci. Původ zhruba desetiny naší dědičné informace lze vystopovat $\mathrm{k}$ virům. Některé (tzv. endogenní retroviry) se zachovaly v lidském geonomu v plné kráse a síle a jsou s to se podle instrukcí vmáčklých do lidské DNA množit (Löwer et al. 1996). Z jiných zbyl jen genetický šrot (International Human Genome Sequencing Consortium, 2001).

Tak, jako se dá ve sběrně starého železa nalézt nejeden cenný artefakt, dá se vydobýt $z$ genetického virového harampádí nejedna užitečná sekvence. Př́kladem může být náš gen kódující bílkovinu syncytin (Mi et al. 2000). Ten získali naši předci od viru, který s jeho pomocí navozoval vlastní fúzi s buněčnou membránou a pronikal tak do nitra buněk hostitele. 


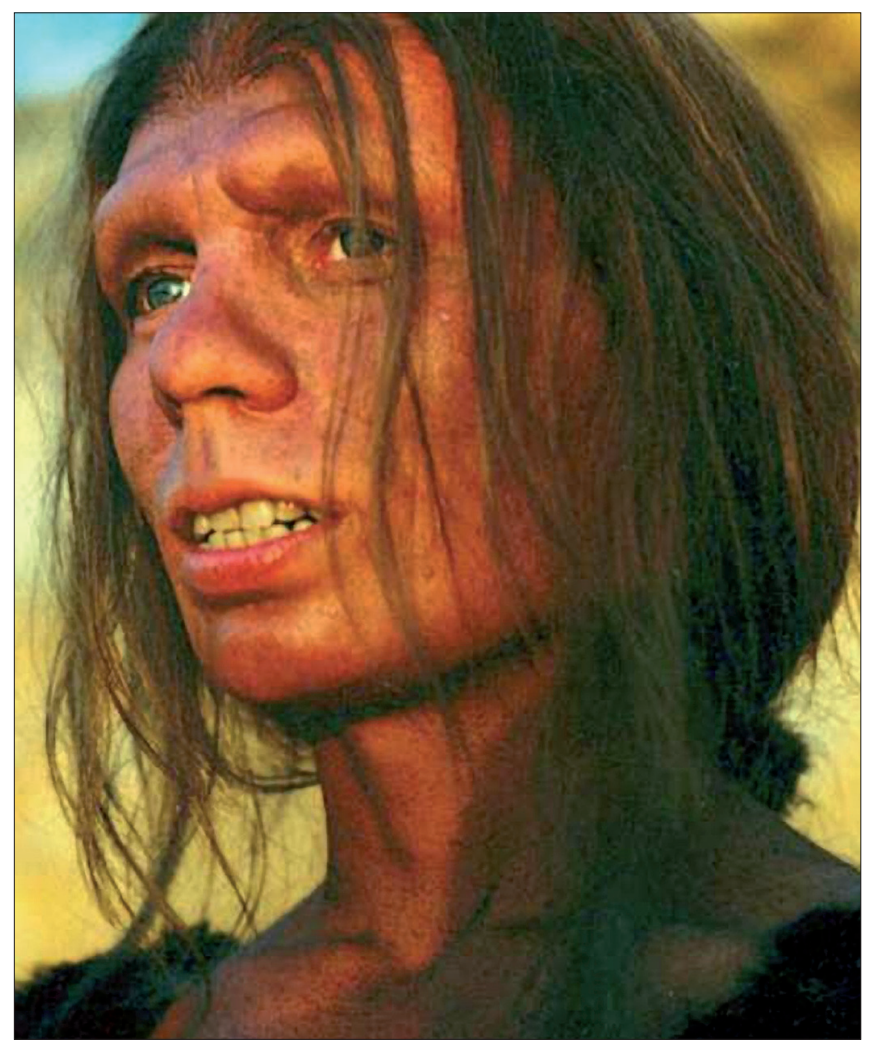

Obr. 1. V našich žilách kolují kapky neandertálské krve. Rekonstrukce neandertálské ženy PLoS Biol 2(12) e449, 2004.

Lidský organismus využívá syncytin $\mathrm{k}$ něčemu podobnému - k vzájemnému splývání buněk v placentě. Díky téhle genetické výpůjčce, pro niž jsme sáhli daleko za hranice genomu vlastního druhu, přicházíme na tento svět.

\section{ČILÝ RUCH NA GENOVÉ BURZE}

Čtení genomů odhaluje, že horizontální přenos genů, při kterém si sekvence DNA vyměňují nejen př́slušníci různých druhů, ale dokonce i odlišných říší, zaujímá v př́rodě a její evoluci podstatně významnější místo, než jaké jsme mu byli donedávna ochotni přiznat (Keeling - Palmer 2008).

$\mathrm{V}$ genomech eukaryotních organismů jsme svědky objevů bezesporu bizarních. Ukazuje se, že různé druhy rostlin si celkem běžně předávají mitochondriální geny (Bergthorsson et al. 2003) a u některých rostlin dosahuje obrat na genové burze úctyhodných proporcí. Například jedna z nejstarších krytosemenných rostlin světa novokaledonská Amborella trichuta získala horizontálním transferem dvě třetiny svých mitochondriálních genů, přičemž pro třetinu výpůjček sáhla dokonce až k mechům (Bergthorsson et al. 2004). Ještě „fantasmagoričtějši “ geny lze pozorovat v dědičné informaci portorického stromu Ternstroemia stahlii (Hao et al. 2010). Jeden $\mathrm{z}$ jeho genů je složen jako puzzle $\mathrm{z}$ pěti dílků původního genu stromu a pěti podstatně větších dílů analogického genu brusnice (Viccinia).
Rozsáhlé výměny sekvencí DNA se nevyhýbají ani živočišné říši. Jasnými přeborníky jsou v tomto ohledu vírníci pijavenky (Bdelloidea), v jejichž genomech lze nalézt sekvence pocházející od bakterií, hub, rostlin i jiných živočichů (Gladyshev et al. 2008).

I u obratlovců nacházíme indicie o tom, že výměny genů nejsou v př́rodě zakázány a odehrávají se zřejmě za vydatného přispění virů a tzv. skákajících genů čili transpozonů. Prakticky identické sekvence dědičné informace získali opakovaným horizontálním transferem tvorové evolučně tak odlišní, jako jsou africké žáby drápatky, americké ještěrky anolisové, jihoamerické vačice, africké komby, madagaskarští bodlíni a severoameričtí netopýři (Pace et al. 2008). Naši obrazotvornost jistě rozdráždí i zatím nedokončený přenos transpozonů mezi africkou zmijí perlovou a její kořistí pískomilem mokřadním. Z krve pískomilů byl izolován virus, který nese ve své dědičné informaci sekvence jasně pocházející ze zmije. Je zřejmě jen otázkou slepé náhody a času, jestli si některý z pískomilů sekvenci svého úhlavního neprrítele přisvojí (Piskurek - Okada, 2007).

Nechce se věřit, že by člověk měl z těchto „genetických handlư “ od přírody garantován generální pardon. Možná jsme v našem genomu výpůjčky od jiných eukaryotů nenašli jen proto, že nám jejich existence připadala „š́lená“ a nikdo se o takové pátrání intenzivněji nepokoušel.

\section{VĚDOMÉ P̌̌EŠLAPY}

Člověk k vlastnímu „genetickému rozkročení vně i dovnitř lidského genomu přispívá stále intenzivnějším využíváním metod genového inženýrství. Na jedné straně exportuje lidské geny do jiných organismů. Zhusta se tak děje ze studijních účelů, ale mnohé genové přesuny mají ryze praktický význam. Prvním prríkladem byl lidský inzulín vyráběný pomocí bakterií nesoucích př́islušný lidský gen (Ladish - Kohlmann 1992). Dnes se podobným zpơsobem vyrábí široká plejáda farmakologicky využitelných lidských proteinů. Výjimkou nejsou ani savci vybavení lidským genem. Např́iklad kozy s genem pro lidský antitrombin vylučují lidský protein v mléce. Ten je po vyčištění využíán jako lék Atryn $\mathrm{k}$ potlačení nadměrné srážlivosti krve u pacientů ohrožených embolií (Edmunds et al. 1998).

Při některých genových terapiích jsme svědky postupu přesně opačného, když vnášíme virové nebo bakteriální geny do dědičné informace vybrané populace buněk lidského těla. Prakticky se tento postup využívá při léčbě nádorových onemocnění (McCormick 2001). Do nádorových buněk v těle pacienta je vnesen lidskému organismu cizí gen, např́iklad gen pro thymidin kinázu herpes simplex viru, a podle něj je v nádoru syntetizován př́slušný protein. Pak je pacientovi podána sloučenina, která v lidském organismu normálně neprochází významnější změnou. Enzym syntetizovaný v nádorových buňkách podle cizího genu však tuto látku přemění na toxickou sloučeninu, která buňky zničí. Destrukce buňky a odhalení vnitrobuněčných struktur může mobilizovat imu- 


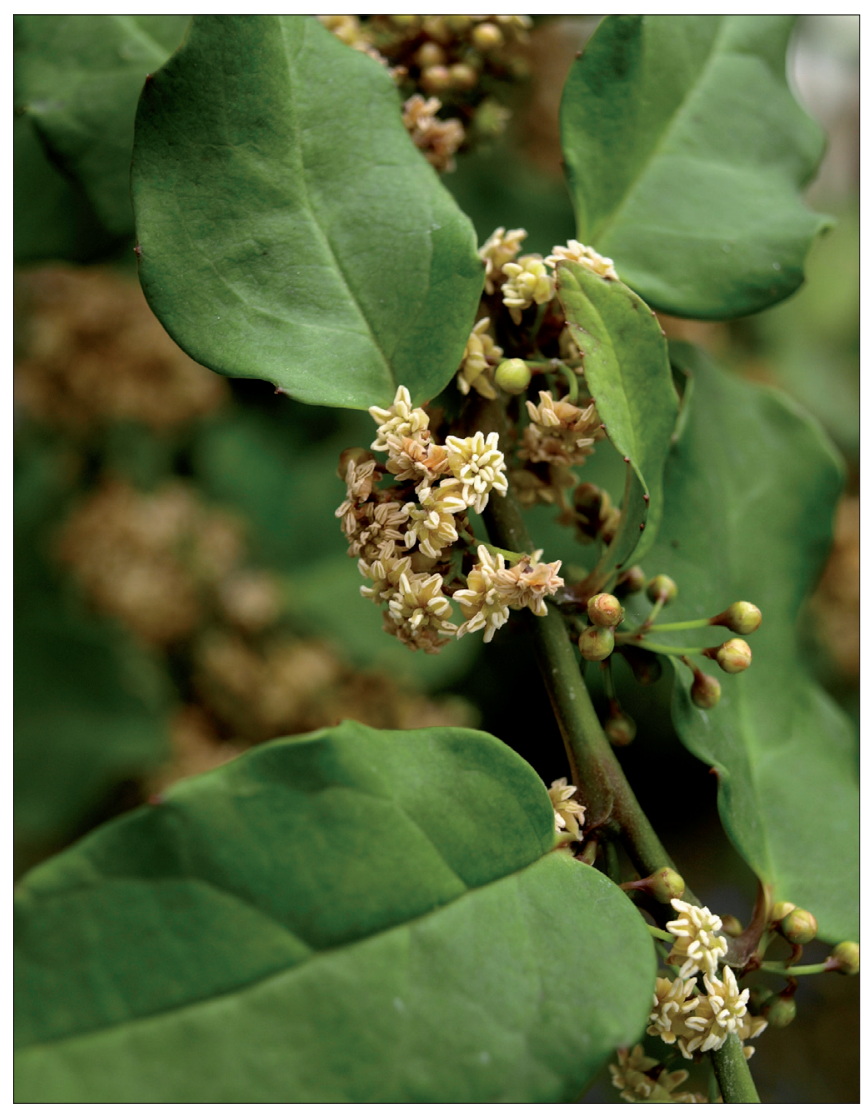

Obr. 2. Krytosemenná rostlina Amborella trichopoda získala horizontálním přenosem genů dědičnou informaci mechů. WikiMedia. http://commons.wikimedia.org/wiki/File:Amborella_trichopoda_(3173820625).jpg

nitní systém pacienta $\mathrm{k}$ ataku na zbývající nádorové buňky. I když jsou podobné postupy motivovány především snahou zmírnit utrpení nemocných, uzdravovat je a zachraňovat jejich životy, otevírají nejednu znepokojivou filozofickou otázku. Mưžeme se např́iklad ptát, nakolik bychom se mohli či měli po konzumaci masa kozy s lidským genem cítit jako kanibalové.

\section{GENETICKÁ „KLOPÝTNUTİ“ PŘEDKŮ}

Prudký rozvoj genomiky a bezprecedentní expanze možností sekvenačních technik otevřel cestu ke vzniku paleogenomiky (Lambert - Miller 2006). Z fragmentů DNA dochované ve fosíliích lze rekonstruovat významné části dědičné informace nebo dokonce celé genomy vyhynulých tvorů. Při rekonstrukci genomů vyhynulých zvírat patří $\mathrm{k}$ hlavním komplikacím odlišení původní dědičné informace živočicha od kontaminace dědičnou informací půdní mikroflóry a dalších organismů. $\mathrm{V}$ př́padě rekonstrukce genomu pravěkého člověka se $\mathrm{k}$ tomu připojuje významné riziko kontaminace fragmenty DNA pocházejícími od zástupců současných Homo sapiens. I tyto technické potíže se však daří eliminovat a díky tomu máme $\mathrm{k}$ dispozici genom neandertálce (Noonan et al. 2006).

Čekalo v něm na nás jedno velké překvapení. Shoda sekvencí se současnou euroasijskou populací Homo sapiens "usvědčila“

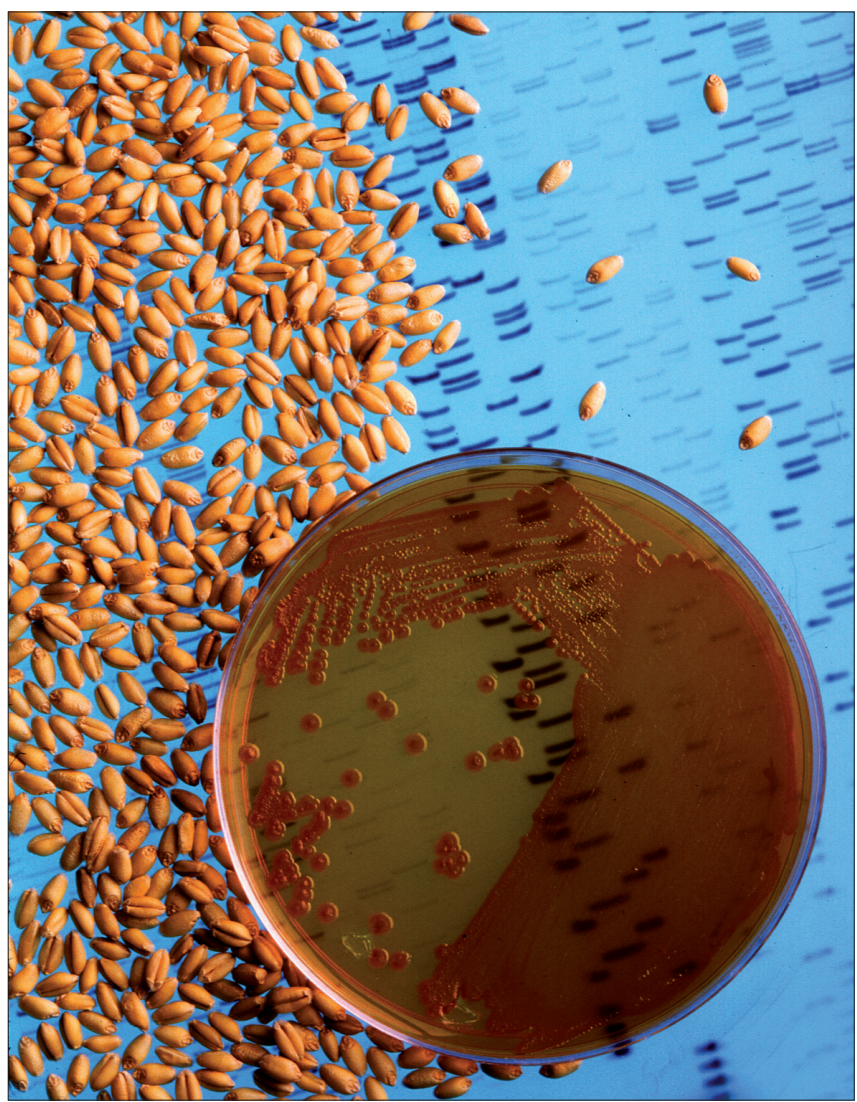

Obr. 3. Genové inženýrství překračuje hranice genomů v zájmu lidstva. Pšenice s uměle vneseným genem bakterie vzdoruje houbovým chorobám. WikiMedia. http://commons.wikimedia.org/wiki/File:Genetic-engineeringwheat.jpg

naše předky z mesaliance s Homo neaderthalensis považovaného do té doby většinou badatelů za slepou vývojovou větev, z jejíhož genomu se nic nedochovalo. Podíl neandertálské DNA v lidském genomu není velký. Pohybuje se mezi 1 až $4 \%$. I to však představuje evidentní „vyšlápnuti“ za ostře narýsované genetické hranice našeho druhu.

Ještě větší překvapení nám připravila moderní genetika a genomika analýzou DNA izolované $\mathrm{z}$ fragmentu kosti prstu pravěké ženy nalezeného v Děnisovově jeskyni na Altaji (Krause et al. 2010). Dědičná informace není shodná ani s DNA Homo sapiens ani s DNA Homo neanderthalensis. Patř́ zatím nepopsanému druhu člověka, který žil na Sibiři před 40000 lety. Úplnější analýzy genomu člověka z Děnisovovy jeskyně (Reich et al. 2010) přinesly další důkaz mesaliance Homo sapiens se zástupci starších vývojových linií člověka. $\mathrm{V}$ dědičné informaci Melanésanů se nachází asi 5\% DNA, jež má původ v dědičné informací předků lidí žijících v Děnisovově jeskyni. Nabízí se otázka, s kolika podobnými vývojovými liniemi se Homo sapiens střetl a zda si při těchto setkáních počínal podobně jako při střetech s děnisovany a neandertálci. Jinak řečeno, nabízí se otázka, kolikrát jsme „vyšlápli“ mimo genetické hřiště nalajnované původním genomem Homo sapiens, jehož genetickou „čistotu“, jak se zdá, zatím „zachraňuji“ obyvatelé subsaharské Afriky, v jejichž genomech se doposud svědectví po dávných mesaliancích nepodařilo odhalit. 


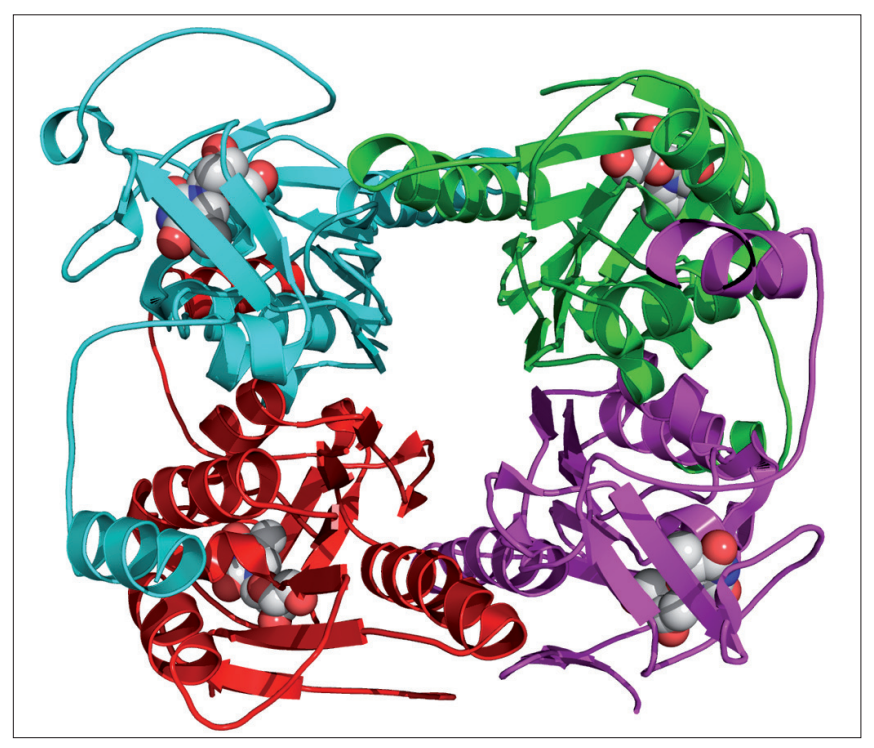

Obr. 4. Enzym thymidin kináza vyrobený podle genů, jež je lidskému organismu cizorodý, může pomoci $\mathrm{k}$ tomu, aby se lidské tělo vypořádalo $\mathrm{s}$ nádorovým onemocněním. WikiMedia http://commons.wikimedia.org/wiki/ File:2B8T.png

\section{KDE JSOU HRANICE LIDSKÉHO GENOMU}

Fakt, že do lidského genomu pronikají cizorodé dědičné elementy a naopak, elementy lidské dědičné informace jsou rozesety př́rodou nebo samotným člověkem mimo lidský genom, je dobrou př́ležitostí $\mathrm{k}$ zamyšlení nad budoucností lidského genomu.

Na jedné straně může genová terapie celkem snadno, a zřejmě i poměrně nepozorovaně, přerůst $\mathrm{v}$ genetické vylepšování člověka (Baylis - Robert 2004), tedy k cíleným změnám lidské dědičné informace, jež si kladou za cíl optimalizaci nebo maximalizaci tělesných či duševních funkcí. Konečnou extrapolací takových snah bude Homo futurensis - bytost uzpůsobená k životu v mezihvězdném prostoru (Birx 2010).

Těžko předpokládat, že by se proces „překračování hranic“ lidského genomu zastavil v okamžiku našeho prvního kontaktu s extraterestriálními formami života. Pokud budou systémy dědičné informace pozemského a mimozemského života kompatibilní, neexistuje dostatečně účinná pojistka proti míšení sekvencí našeho genomu se sekvencemi DNA mimozemských virů a bakterií.

Pokud se v budoucnu setkáme se zástupci inteligentní mimozemské civilizace a budeme schopni s nimi obcovat, navážeme možná v jen mírně civilizovanější formě na časy, kdy si druh Homo sapiens vyměňoval sekvence DNA v př́tmí jeskyně se zástupci Homo neanderthalensis či děnisovanů.

Lidé jsou ve své podstatě velmi konzervativní, což se projevuje ve chvályhodné snaze udržet kulturní tradice, chránit historické památky a nenarušenou prrírodu. Stejně tak jsme v pokušení konzervovat současný stav lidského genomu (Kass 1997), i když ten se významně měnil i v historicky nepř́iliš vzdálených dobách (Sabeti et al. 2002). Snahy o konzervaci lidského genomu se stále jasněji ukazují jako naivní. „Genomoví konzervativci" sice prohlašují vizi ustrnulého lidského genomu za „prrírodní či „přrirozenou“, ale to nic nezmění na skutečnosti, že př́roda jim při „ochraně“ lidské dědičné informace proti změnám nebude pokorným spojencem nýbrž zdatným protivníkem.

Už dnes nepředstavuje lidský genom obraz s ostrými a jasně definovanými konturami, jaký bychom mohli přirovnat nejspiše ke školnímu rysu narýsovaného tuší o hodinách deskriptivní geometrie. Jde o obraz neurčitých kontur srovnatelný nejspíše s plátny impresionistů. Není proto horší nebo ošklivější. Spiše naopak. Jeho další posun k fúznímu stavu nebude jistě bez rizik, ale nebude ani bez půvabu.

\section{LITERATURA}

Anderson, M. T. - Seifert, H. S. (2011): Opportunity and Means: Horizontal Gene Transfer from the Human Host to a Bacterial Pathogen. mBio, 2, e00005-000011.

Baylis, F. - Robert, J. J. (2004): The inevitability of Genetic Enhancement Technologies. Bioethics, 18, 1-26.

Bengthorsson, U. - Adams, K. L. - Thomason, B. - Palmer, J. D. (2003) Widespread Horizontal Transfer of Mitochondrial Genes in Flowering Plant. Nature, 424, 197-201.

Bergthorsson, U. - Richardson, A.O. - Young, G. J. - Goertzen, L. R. - Palmer, J. D. (2004): Massive Horizontal Transfer of Mitochondrial Genes from Diverse Land Plants Donors to the Basal Angiosperm Amborella. Proceedings of the National Academy of Sciences U.S.A., 101, 17747-17752.

Birx, H. J. (2010): Evolution: As I See It. Anthropologia Integra, 1 (2), 7-10.

Edmunds, T. - Van Patten, S. M. - Pollock, J. - Hanson, E. - Bernasconi, R. - Higgins E. - Manavalan, P. - Zlomek, C. - Meade, H. - McPherson, J. M. - Cole J. S. (1998): Transgenically Produced Human Antithrombin: Structural and Functional Comparison to Human Plasma-Derived Antithrombin. Blood, 91, 4561-4571.

Gladyshev, E. A. - Meselson, M. - Arkhipova, I. R. (2008): Massive Horizontal Gene Transfer in Bdelloid Rotifers. Science, 320, 1210-1213.

Hao, W. - Richardson, A. O. - Zheng, Y. - Palmer, J. D. (2010): Gorgeous Mosaic of Mitochondrial Genes Created by Horizontal Transfer and Gene Conversion. Proceedings of the National Academy of Sciences U.S.A., 107, 21576-21581.

International Human Genome Sequencing Consortium (2001): Initial Sequencing and Analysis of the Human Genome. Nature, 409, 860-921.

Kass, L. J. (1997): The Wisdom of Repugnance. New Republic, 216, 17-27.

Keeling, P. J. - Palmer, J. D. (2008): Horizontal Gene Transfer in Eukayriotic Evolution. Nature Reviews Genetics, 9, 605-618).

Krause, J. - Fu, Q. - Good, J. M. - Viola B. - Shunkov, M. V. - Derevianko, A. P. - Pääbo, S. (2010): The Complete Mitochondrial DNA Genome of an Unknown Hominin from Southern Siberia. Nature, 464, 894-897

Ladisch, M. R. - Kohlmann, K. L. (1992): Recombinant Human Insulin. Biotechnology Progress, 8, 469-478.

Lambert, D. M. - Millar, C. D. (2006): Evolutionary Biology: Ancient Genomics Is Born. Nature, 444, 275-276.

Löwer, R. - Löwer, J. - Kurth, R. (1996): The Viruses in All of Us: Characteristics and Biological Significance of Human Endogenous Retrovirus Sequences. Proceedings of the National Academy of Sciences, 93, 5177-5184.

McCormick, F.(2001): Cancer Gene Therapy: Fringe or Cutting Edge? Nature Reviews Cancer, 1, 130-141.

Mi, S. - Lee, X. - Li, X.-P. - Veldman, G. M. - Finnerty, H. - Racie, L. - LaVallie, E. - Tang, X.-Y. - Edouard, P. - Howes, S. - Keith, J. C. - McCoy, J. C. (2000): Syncytin Is a Captive Retroviral Envelope Protein Involved in Human Placental Morphogenesis. Nature, 403, 785-789.

Noonan, J. P. - Coop, G. - Kudaravalli, S. - Smith, D. - Krause, J. - Alessi, J. - Chen F. - Platt D. - Pääbo, S. - Pritchard, J. K. - Rubin, E. M. (2006): Sequencing and Analysis of Neanderthal Genomic DNA. Science, 314, 1113-1118. 
Pace, J. K. - Gilbert, C. - Clark, M. S. - Feschotte, C. (2008) Repeated Horizonatal Transfer of a DNA Transposon in Mammals and other Tetrapods. Proceedings of the National Academy of Sciences U.S.A., 105, 17023-17028.

Piskurek, O. - Okada, N. (2007) Poxviruses as Possible Vectors for Horizontal Transfer of Retroposons from Reptiles to Mammals. Proceedings of the National Academy of Sciences U.S.A., 104, 12046-12051.

Reich, D. - Green, R. E. - Kircher, M. - Krause, J. - Patterson, N. - Durand, N. - Viola, B. - Briggs, A. W. - Stenzel, U. - Johnson, P. L. F. - Maricic, T. - Good, J. M. - Marques-Bonet, T. - Alkan, C. - Fu, Q. - Mallick, S. - Li, H. - Meyer, M. - Eichler, E. E. - Stoneking, M. - Richards, M. - Talamo, S. - Shunkov, M. V. - Derevianko, A. P. - Hublin, J.-J. - Kelso, J. - Slatkin, M. - Pääbo, S. (2010): Genetic History of an Archaic Hominin Group from Denisova Cave in Siberia. Nature, 468, 1053-1060.

Sabeti, P. C. - Reich, D. E. - Higgins, J. H. - Levine, H. Z. P. - Richter, D. J. - Schaffner, S. F. - Gabriel, S. B. - Platko, J. B. - Patterson, N. J. - McDonald, G. J. - Ackerman, H. C. - Campbell, S. J. - Altshuler, D. - Cooper, R. - Kwiatkowski, D. - Ward R. - Lander E. S. (2002): Detecting Recent Positive Selection in the Human Genome from Haplotype Structure. $\mathrm{Na}$ ture, 419, 832-837.

\section{AUTOR}

Petr, Jaroslav (3. 8. 1958, Kolín), český biotechnolog. Pracuje jako vedoucí výzkumný pracovník ve Výzkumném ústavu živočišné výroby v Praze-Uhříněvsi, kde se zabývá reprodukční biologií a biotechnologiemi hospodářských zviŕat. Přednáší externě na České zemědělské univerzitě v Praze, na Př́rodovědecké fakultě Univerzity Karlovy v Praze a na Biologické fakultě Jihočeské univerzity v Českých Budějovicích. Věnuje se též popularizaci vědy (kniha Když jdou ryby rybarit. Vědecké fejetony o přírodě z vysílání Českého rozhlasu Leonardo. Praha: Radioservis, Český rozhlas Leonardo, 2010; články in: www. osel.cz; Neviditelný pes; Lidové noviny aj.) a psaní sci-fi povídek.

Kontakt: Prof. Ing. Jaroslav Petr, DrSc. (M.Sc., Ph.D., Sc.D), Výzkumný ústav živočišné výroby, v. v. i., Přátelství 815, 10401 Praha 10-Uhř́něves, telefon: + 420 267009646, e-mail: petr@vuzv.cz. 